日泌尿会誌，83巻， 8 号，1992年：1228 1237

腎細胞癌に括ける組織, 血液, 尿中ポリアミンの臨床的意義

岐阜大学医学部泌尿器科学教室 (主任: 河田幸道教授)

小出 卓 也

\title{
THE CLINICAL SIGNIFICANCE OF TISSUE, BLOOD AND URINE POLYAMINE IN RENAL CELL CARCINOMA
}

\author{
Takuya Koide \\ Department of Urology, Gifu University School of Medicine \\ (Director: Prof. Y. Kawada, M.D.)
}

With the use of a newly developed and convenient enzymatic method, tissue, urine and blood polyamine (diamine, spermidine and spermine) levels were evaluated as a tumor marker of renal cell carcinoma (RCC) in 50 cases with the disease. Furthermore, blood and urine polyamines were periodically determined and evaluated as a follow-up marker. The pretreatment three polyamine levels in tissue, blood and urine of the patients were all significantly higher than those of the controls. However, because of their low sensitivities, they were not always decisive for biochemical diagnosis of RCC. Tissue spermidine levels were increased with the advance of the stages. Tissue diamine level also showed a good correlation with the pathological grade. Tissue diamine was found to predict distant metastasis. Blood spermidine and urine diamine were useful as follow-up markers. In conclusion, combined determination of tissue, blood and urine polyamine levels was thought to be useful as tumor markers of RCC.

Key words: polyamine, renal cell carcinoma, tumor marker

要旨：腎細胞癌50例の組織，血液および尿中のポリアミン(diamine， spermidine， spermine)を新しい 簡便な酵素法により分別定量し，腫瘍マーカーとしての臨床的意義を検討した．癌患者群では対照群に 対し，組織中の spermidine $(\mathrm{p}<0.01)$ ，血中の 3 分画 $(\mathrm{p}<0.05)$ ，尿中の diamine および spermidine $(\mathrm{p}<$ 0.05)などが，有意に高値を示した。組織，血液および尿中の 3 分画とも病期が進むにつれて高值を示 し, 特に組織中の spermidine に拈いて顕著であった。組織中の diamine は組織学的異型度が進むにつれ て高値を示した。また，組織中の diamine は転移性再発の有無との相関を示した。術後の経過観察中に 転移性再発を示した 9 例の血液および尿について検討したところ, 血中の spermidine と尿中の diamine が，転移性再発後に有意に高值を示した（p<0.01）。しかし，非再発例では，血液および尿中の 3 分画 は有意な上昇を示さなかった。治療経過㘧よび転移性再発の指標として, 特に血中の spermidine および 尿中の diamine が有用であると思われた，以上より，組織，血液および尿中のポリアミンは，組み合わ せて測定することにより腎細胞癌の腫瘍マーカーとして病態を把握するらえで有意義であると思われ た。

キーワード：ポリアミン, 腎細胞癌, 腫瘍マーカー

\section{緒 言}

ポリアミンは, 複数のアミノ基を有する直鎖の脂肪 族炭化水素化合物の総称であり,生物界に広く存在し, 核酸やタンパク質の合成や安定化，あるいは細胞の増 殖や機能的分化に重要な役割を果たしていることが知 られている. 1971年 Russell らが癌患者における尿中
ポリアミンの増加を報告して以来, 腫瘍マーカーとし て注目され，尿のほか血液 ${ }^{2)}$ ・脳脊髄液 ${ }^{2}$ などの各種体 液中で測定されて臨床的に検討されている。ささらに, 細胞増殖の盛んな癌組織ではポリアミンの合成, 蓄積 が亢進し細胞内濃度が増加しているといわれ，体液中 のポリアミン值には悪性腫瘍病巣との相関において不 
安定な要素があることから, 腫瘍組織中のポリアミン の測定が望まれている4).

われわれは, 従来のアミノ酸分析法 ${ }^{2}$ や高速液体ク ロマトグラフ法5などに比して，新しい簡便な酵素法 を開発して, 尿路性器癌患者の組織6), 血液 ${ }^{7)}$, 尿 ${ }^{8)}$ に打 けるポリアミン濃度を測定し，その臨床的意義につい て検討してきた. 今回, 有力な特異的腫瘍マーカーが 未だ確立されていない腎細胞癌について, 組織, 血液, 尿中のポリアミンを測定し，血液および尿に関しては 長期間の経過観察を加えて, 腫瘍マーカーとしてのポ リアミンの臨床的意義を検討したので報告する。

\section{対象および方法}

対象は主に岐阜県立岐阜病院で手術を施行し, 組織 学的に腎細胞癌と診断された 50 例（男子 38 例, 女子 12 例, 平均年齢63.1歳）である。病期はRobson らの分 類 ${ }^{9}$ に従い, stage I 18例, stage II 14例, stage III 9 例, stage IV 9 例であった. 組織学的異型度は腎癌取 扱い規約 ${ }^{10)}$ に従い, G1 12例, G2 35例, G3 3 例であっ た. 組織学的細胞型も腎癌取扱い規約 ${ }^{10)}$ に従い, clear cell type 40例, alveolar cell type 7 例, mixed cell type 3 例であった. 術前に遠隔転移を認めなかった stage I III の41例について, 術後 $1 \sim 4$ 年の経過観察 中に転移性再発を認めた転移性再発例は 9 例であり, 術後 1 年以上再発を認めなかった非再発例は32例で あった。
対照としては, 組織に関してはそれぞれの摘出腎か ら肉眼的・組織学的に健常部の腎皮質組織を採取して

Fig. 1 Principles and methods for determination of diamine, spermidine and spermine

\footnotetext{
Reaction I Spm., Spd., Put., Cad. Dia. Addition of PUO (around PH 8.0) Amount of $\mathrm{H}_{2} \mathrm{O}_{2}=$ Spd. + Put. + Cad. Dia.
Reaction II Spm., Spd., Put., Cad. Dia. Amount of $\mathrm{H}_{2} \mathrm{O}_{2}=\mathrm{Spd}$. $+\underbrace{\text { Put. }+\mathrm{Cad} \text {. }}$ Dia. Amount of $\mathrm{H}_{2} \mathrm{O}_{2}=2 \mathrm{Spm}$.
Amount of $\mathrm{H}_{2} \mathrm{O}_{2}=\mathrm{Spd} .+\underbrace{\text { Put. }+ \text { Cad. }}+2 \mathrm{Spm}$ Dia. - Addition of PUO (around PH 8.0) Addition of PAO (around PH 6.0)

Calculation of Diamine, Spermidine, Spermine $D_{i a}=K\left(A_{I I}-A_{I I I}\right), S p d=K\left(A_{I}+A_{I I I}-A_{I I}-\right.$ blank $), S p m=\frac{1}{2} K\left(A_{I I}-A_{I}\right)$
}

Fig. 2 Protocols for isolation and determination of polyamine in tissue

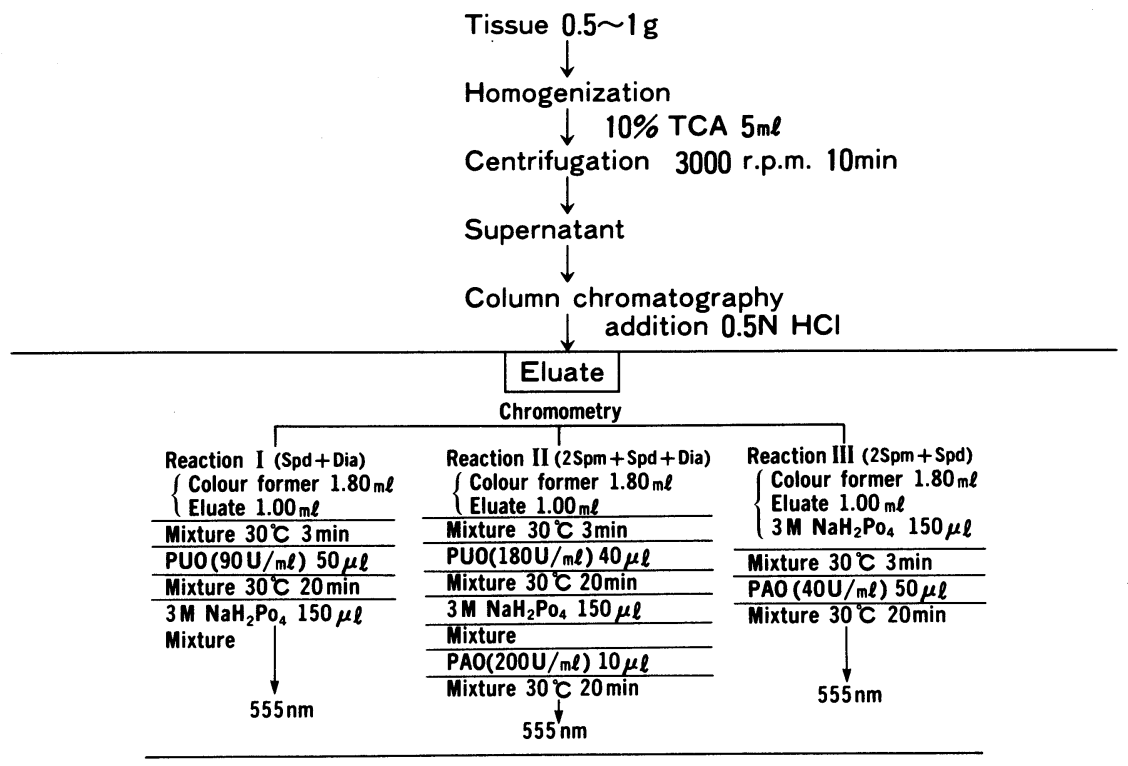


測定し，血液は健常成人 25 例，尿は健常成人 20 例から 採取した。

測定原理は第 1 報 $^{11)}$ で詳説した（Fig. 1)．測定方法 は，既報11) 13)で述べたとおり，組織，血液および尿を それぞれ前処理後，陽イオン交換樹脂を含むカラムに

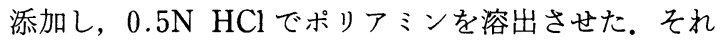
らに，基質特異性の異なるプトレッシン酸化酵素 (PUO) 拈よびポリアミン酸化酵素（PAO）の 2 種類 のアミン酸化酵素を加えて発生する $\mathrm{H}_{2} \mathrm{O}_{2}$ を比色定量 することにより, diamine (putrescine+cadaverine, Dia), spermidine (Spd) 括よび spermine (Spm)を 分別定量した（Fig. 2). 血中ポリアミンは Ht 值で補 正し7)，尿中ポリアミンは随時尿を creatinine 值で補 正し ${ }^{8)}$, 組織中ポリアミンは, Lowry $ら^{14)}$ の方法で測定 したタンパク量当たりの含量として検討した ${ }^{6)}$. 検体

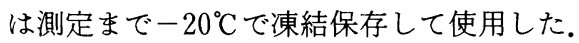

統計処理は $\mathrm{t}$ 検定を用い, 危険率 $5 \%$ 以下を有意と した。また，組織，血液掞よび尿中の 3 分画の相互関 係についてはP Pearsonの相関分析を用いた。

\section{結果}

1. 組織中のポリアミン濃度

結果をTable 1 抢よび Fig. 3〜5 に示した。癌組織 50 例と健常組織 50 例とを比較検討すると， 3 分画とも 癌組織の方が健常組織に比して高值を示し, 特に Spd は有意に高值を示した $(\mathrm{p}<0.01)$. 病期別に検討する と, 3 分画とも stage I・II より stage III・IV の方が
Fig. 3 Distribution of diamine concentration in normal and cancerous tissue from the patients with RCC

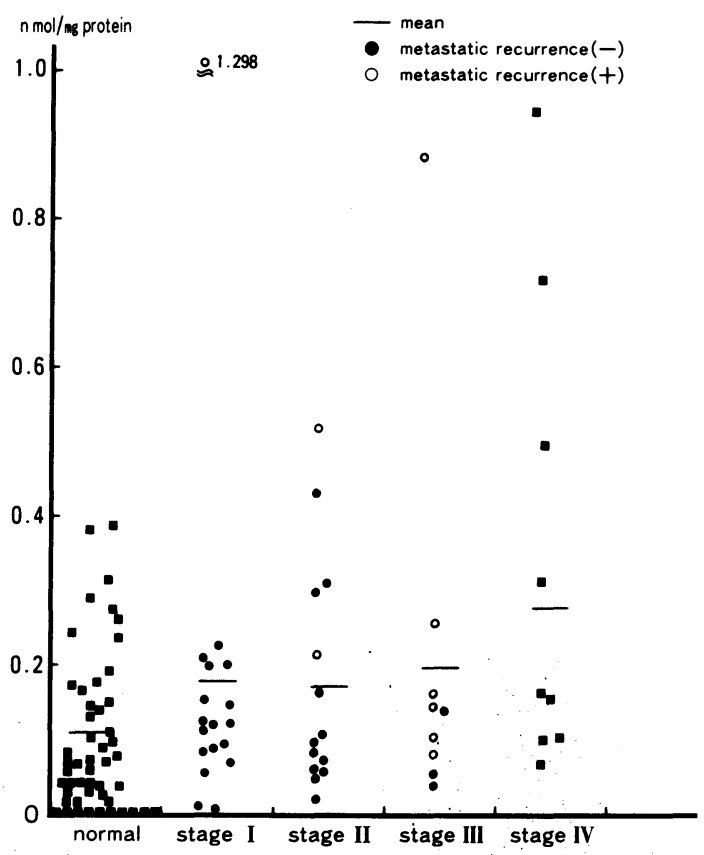

高值を示し, stage III と stage IV との比較でも stage IV の方が高值を示した．特に Spd は病期が進むとと もに高值を示す傾向がより顕著であった，組織学的異 型度別の検討では, G3の症例数が 3 例と少ないもの

Table 1 Polyamine concentrations and ratios in normal and cancer tissues from patients with renal cell carcinoma in terms of histological or clinical findings

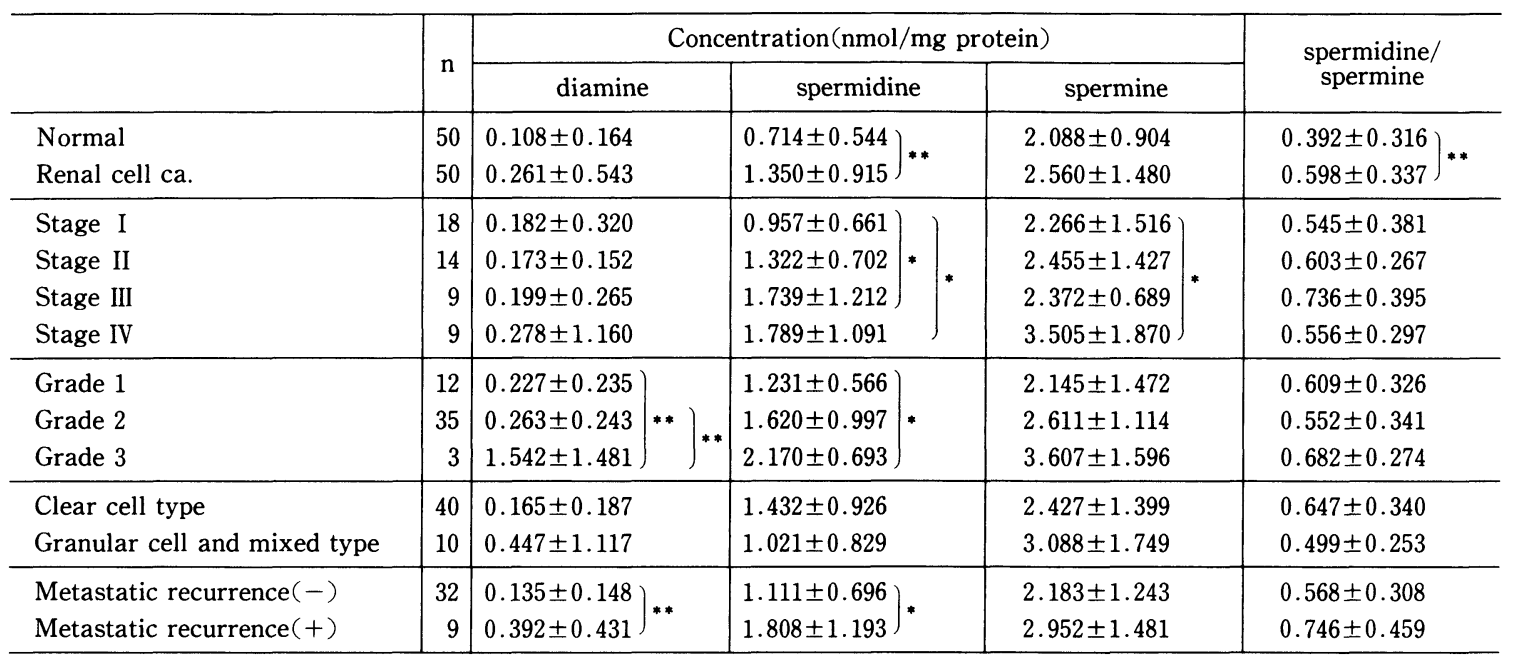

$($ Mean \pm SD) * $\mathrm{p}<0.05 * * \mathrm{p}<0.01$ 
Fig. 4 Distribution of spermidine concentration in normal and cancerous tissue from the patients with RCC

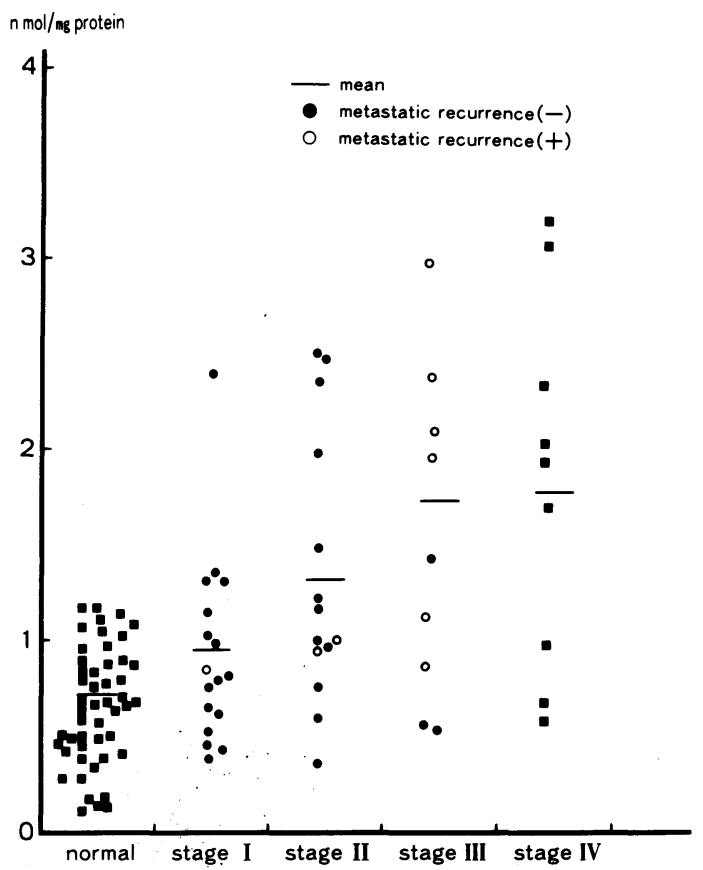

の，3 分画とも G1から G2，さらに G3になるにつれ高 値を示した。 特にDiaにその傾向が強くみられた．組 織学的細胞型別の検討では, clear cell type 40例と,
Fig. 5 Distribution of spermine concentration in normal and cancerous tissue from the patients with RCC

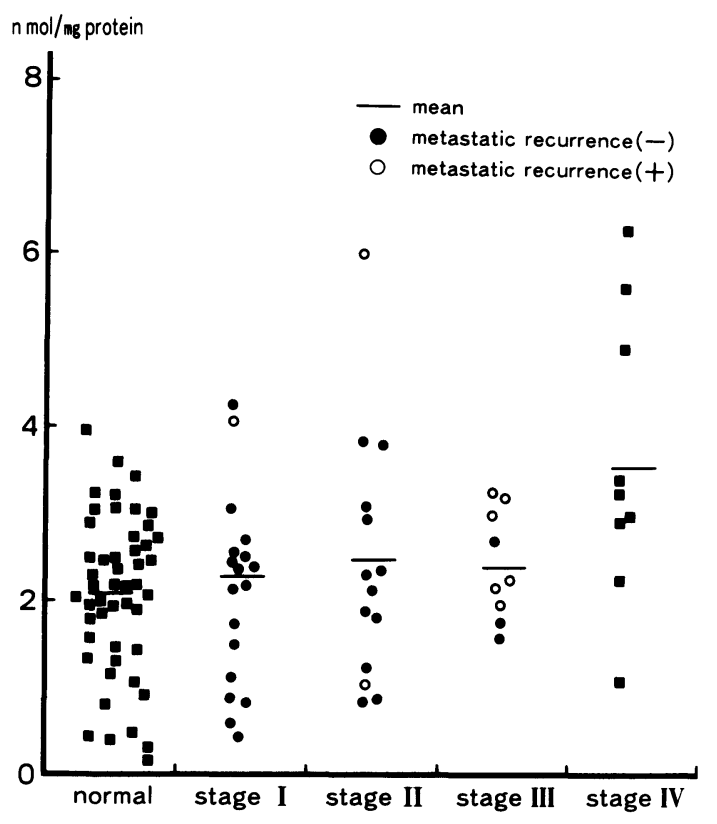

それ以外の type 10例との間に有意の差は認められな かった。転移性再発例 9 例と非再発例32例との比較検 討では, 3 分画とも転移性再発例の方が非再発例に比 し高值を示し，特にDiaは有意に高值を示した（p<

Table 2 Polyamine concentrations and ratios in blood from patients with renal cell carcionma in terms of histological or clinical findings

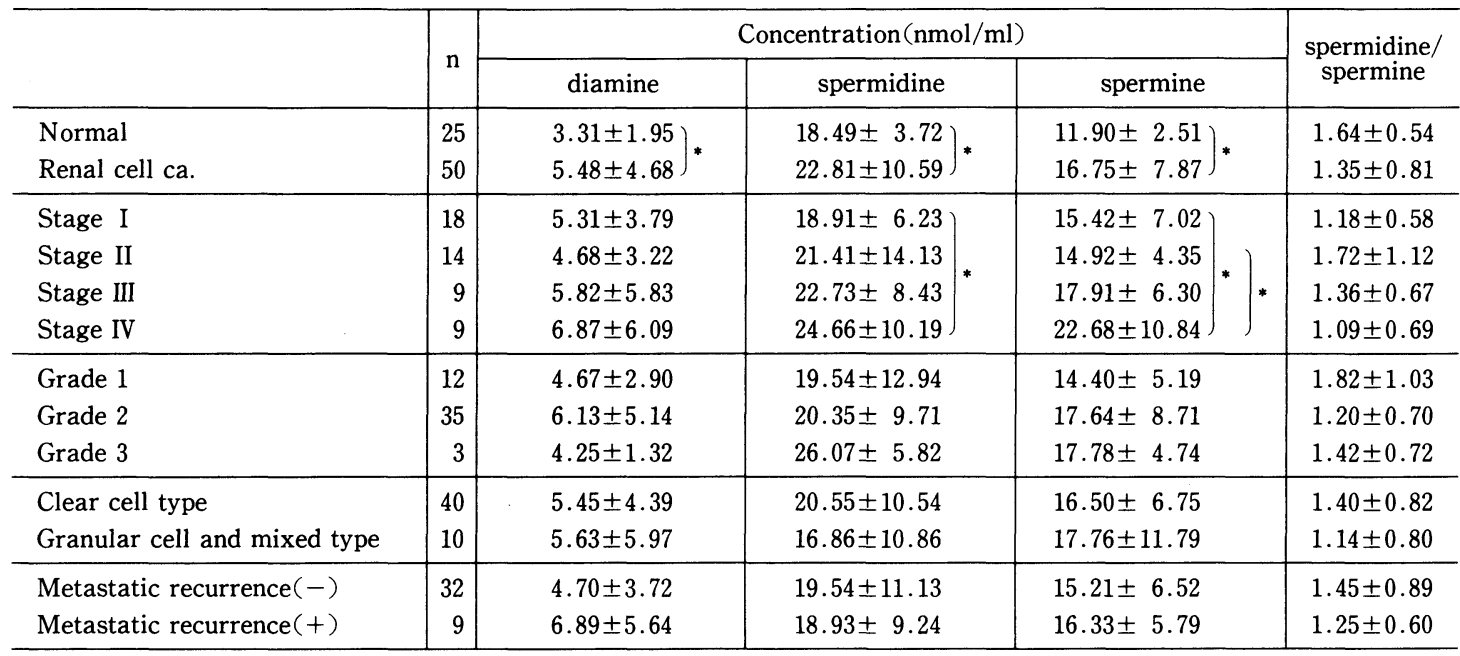

$($ Mean \pm SD) $* \mathrm{p}<0.05$ 
Table 3 Changes of blood and urine polyamine levels by nephrectomy and relapse

\begin{tabular}{l|l|l|l|l}
\hline & \multicolumn{3}{|c|}{ Concentration } & spermidine/ \\
\cline { 2 - 4 } & \multicolumn{1}{|c|}{ diamine } & spermidine & spermine & \\
\hline Blood(nmol/ml) & & & & \\
Pre-ope & $6.89 \pm 5.64$ & $18.93 \pm 9.24$ & $16.33 \pm 5.79$ & $1.25 \pm 0.60$ \\
NED & $4.67 \pm 3.35$ & $17.07 \pm 7.23$ & $13.86 \pm 3.68$ & $1.21 \pm 0.50$ \\
Relapse & $5.97 \pm 3.03$ & $30.84 \pm 17.40$ & $15.45 \pm 6.11$ & $1.53 \pm 1.01$ \\
\hline Urine $(\mu \mathrm{mol} / \mathrm{g}$. Cr.) & & & & \\
Pre-ope & $27.64 \pm 20.34$ & $4.16 \pm 2.58$ & $1.32 \pm 1.21$ & $5.99 \pm 5.04$ \\
NED & $17.65 \pm 8.31$ & $2.14 \pm 1.15$ & $1.07 \pm 0.61$ & $4.78 \pm 2.16$ \\
Relapse & $26.57 \pm 9.39$ & $3.19 \pm 1.55$ & $1.44 \pm 1.00$ & $4.08 \pm 2.41$ \\
\hline
\end{tabular}

$(\mathrm{n}=9) \quad($ Mean $\pm \mathrm{SD}) \quad * * \mathrm{p}<0.01$

0.01)。転移性再発例 9 例中 stage III が 6 例と多数を 占めたが, Fig. 3〜 5 に示すように同じ stage III の中 でも転移性再発例は， 3 分画とも非再発例に比して高 值を示す傾向がみられた。 また， stage I III で G2の 症例28例において, 転移性再発例 5 例と非再発例23例 とを比較検討したところ, Dia は転移性再発例が $0.363 \pm 0.473 \mathrm{nmol} / \mathrm{mg}$ protein で, 非再発例の $0.131 \pm 0.144 \mathrm{nmol} / \mathrm{mg}$ protein に比し有意に高值を 示した. SpdおよびSpmではこのような傾向はみら れなかった。

\section{2. 血中のポリアミン濃度 (Table 2)}

治療前の癌患者50例は健常人 25 例に比し， 3 分画と も有意に高值を示した $(\mathrm{p}<0.01)$. 病期別に検討する と, 3 分画とも stage I・II より stage III・IV の方が 高値を示し, stage III と stage IV との比較では stage IV の方が高值を示した. 組織学的異型度および組織学 的細胞型別の検討では 3 分画とも有意の差は認められ なかった。

転移性再発例 9 例と非再発例 32 例について, 術前の 値を比較検討したが， 3 分画とも有意の差は認められ なかった。 また，転移性再発例 9 例について，腎摘出 術の前 (以下，治療前と略す)，腎摘出術を施行した 1 カ月以上後で化学療法や放射線療法などを受けていな 、時点 (以下, 治療後と略す), 転移が判明した後 (以 下，転移性再発後と略す）のそれぞれ 3 つ時点で検 討した (Table 3)．３分画とも治療後は治療前に比し て低值を示し，転移性再発後は治療後に比して高值を 示した，特に，Spd は転移性再発の前後で上昇を示す 症例が多く（Fig. 6), 治療後の $17.07 \pm 7.23 \mathrm{nmol} / \mathrm{ml}$ に比し, 転移性再発後は30.84 $17.40 \mathrm{nmol} / \mathrm{ml}$ と有意 に高値を示した $(\mathrm{p}<0.01)$. 一方, 非再発例 32 例では,
Fig. 6 Changes of spermidine levels in blood due to occurrence of metastasis

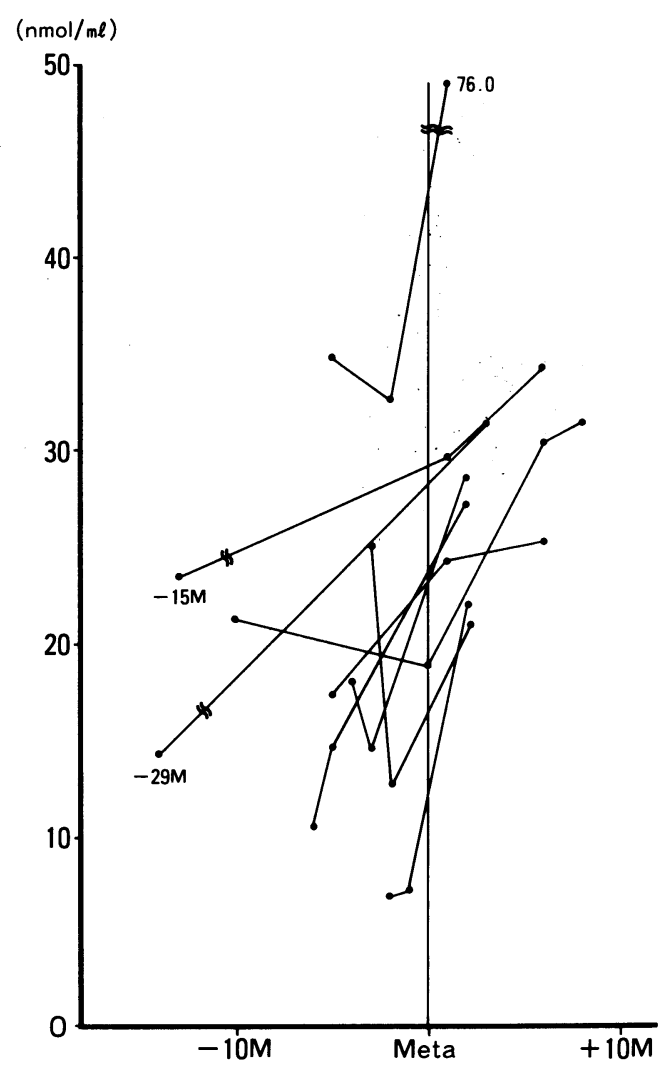

Spd をはじめ 3 分画とも治療前に比し治療後の方が低 值を示したが，その後の経過観察中に著明な上昇を示 すものは認められなかった（Fig. 7)。ささらに，術前に 遠隔転移を認めた stage IV の症例 9 例の腎摘出術前 後のポリアミン值を比較すると, 治療前に比し治療後 
Fig. 7 Changes of spermidine levels in blood after nephrectomy

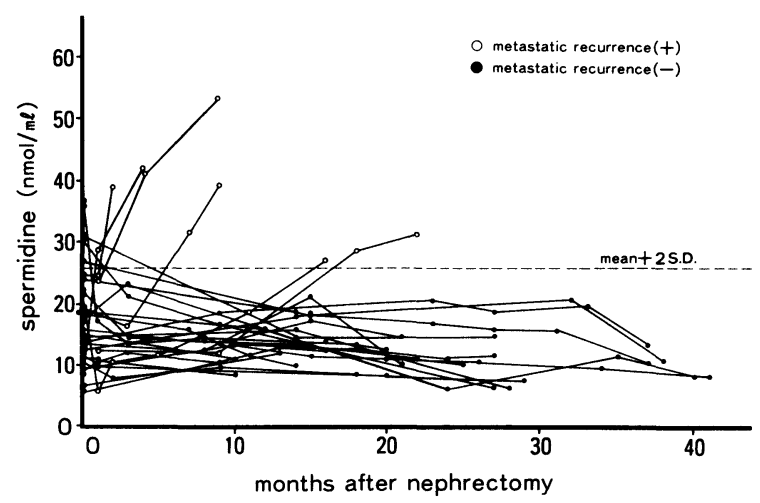

Table 4 Positive ratios

\begin{tabular}{l|c|r|c|c|c}
\hline & & $\mathrm{n}$ & Diamine & Spermidine & Spermine \\
\hline Blood & Stage I & 18 & 33.3 & 16.7 & 22.2 \\
& Stage II & 14 & 28.6 & 28.6 & 28.6 \\
& Stage III & 9 & 22.2 & 33.3 & 44.4 \\
& Stage IV & 9 & 22.2 & 44.4 & 55.5 \\
\hline \multirow{6}{*}{ Urine } & Total & 50 & 28.0 & 28.0 & 34.0 \\
& Stage I & 18 & 22.2 & 27.8 & 11.1 \\
& Stage II & 14 & 28.6 & 21.4 & 14.3 \\
& Stage III & 9 & 55.5 & 22.2 & 33.3 \\
& Stage IV & 9 & 44.4 & 55.5 & 66.6 \\
\hline & Total & 50 & 34.0 & 30.0 & 26.0 \\
\hline
\end{tabular}

(\%)
の方が Spd をはじめ 3 分画とも低值を示し, 術後の経 過観察においては全身状態の増悪とともにポリアミン 各分画の値も上昇する傾向がみられた。

健常人群の mean+2S.D. を越えるものを陽性とし た場合の陽性率について病期別に検討したが, Stage I・IIは 3 分画とも 10～30\%前後と低い陽性率を示した のみであった (Table 4).

3. 尿中のポリアミン濃度（Table 5)

治療前の癌患者 50 例と健常人 20 例とを比較検討する と, 3 分画とも癌患者の方が健常人に対して高値を示 し, 特にDia と Spd は有意に高値を示した。病期別に 検討すると， 3 分画とも stage I から stage IV へと進 むにつれて高値を示す傾向がみられた．組織学的異型 度別に検討すると, Dia において G1から G3へと進む につれて高値を示す傾向がみられた。組織学的細胞型 別の検討では 3 分画とも有意の差は認められなかっ た。

転移性再発例 9 例之非再発例32例について, 術前の 値を比較検討したが，3 分画とも有意の差は認められ なかった。 また，転移性再発例 9 例について，血中ポ リアミンと同様に治療前, 治療後, 転移性再発後のそ れぞれ 3 つの時点で検討した (Table 3). 3 分画とも 治療後は治療前に比して低下し, 転移性再発後は治療 後に比して高値を示した. 特に, Dia は転移性再発後が 治療後に比して $\mathrm{p}<0.01$ で有意の高值を示し，転移性 再発の前後で上昇する症例が多かった(Fig. 8). 一方,

Table 5 Polyamine concentrations and ratios in urine from patients with renal cell carcinoma in terms of histological or clinical findings

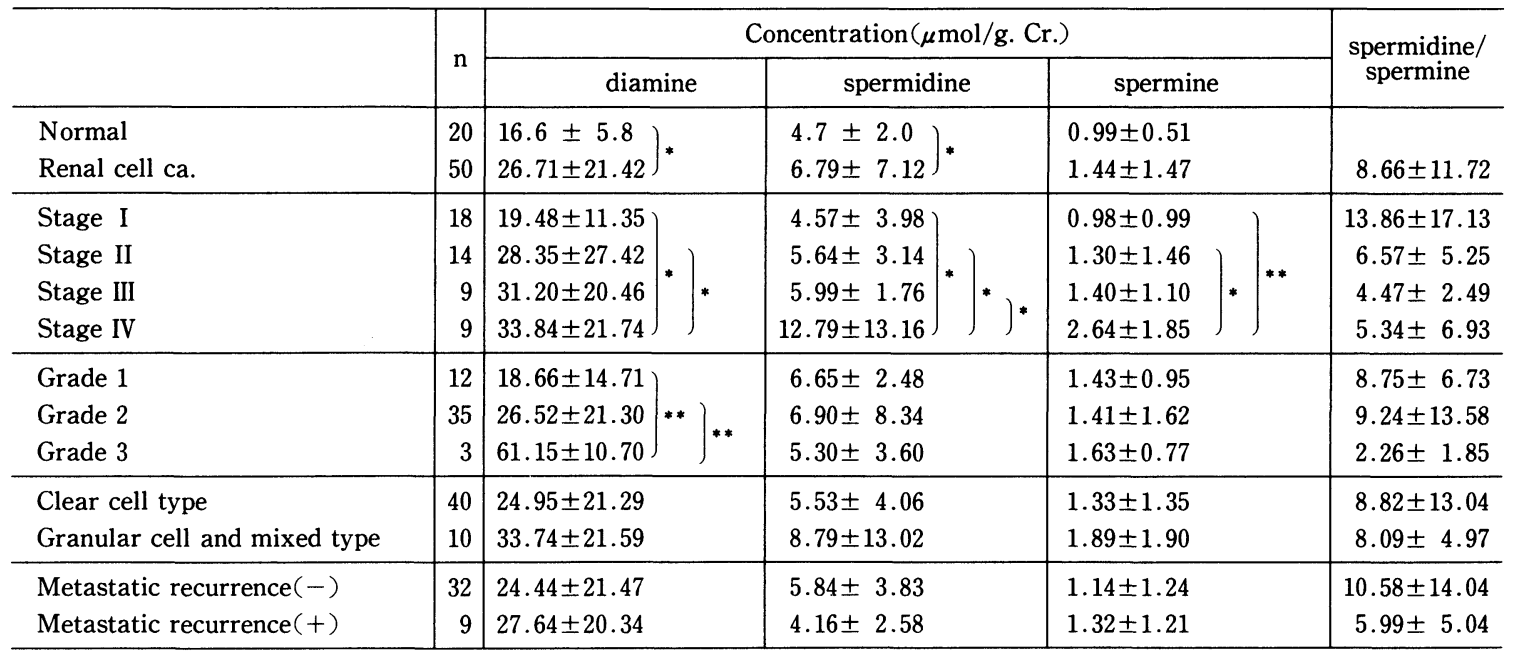

$($ Mean \pm SD) $* \mathrm{p}<0.05 * * \mathrm{p}<0.01$ 
Fig. 8 Changes of diamine levels in urine due to occurrence of metastasis

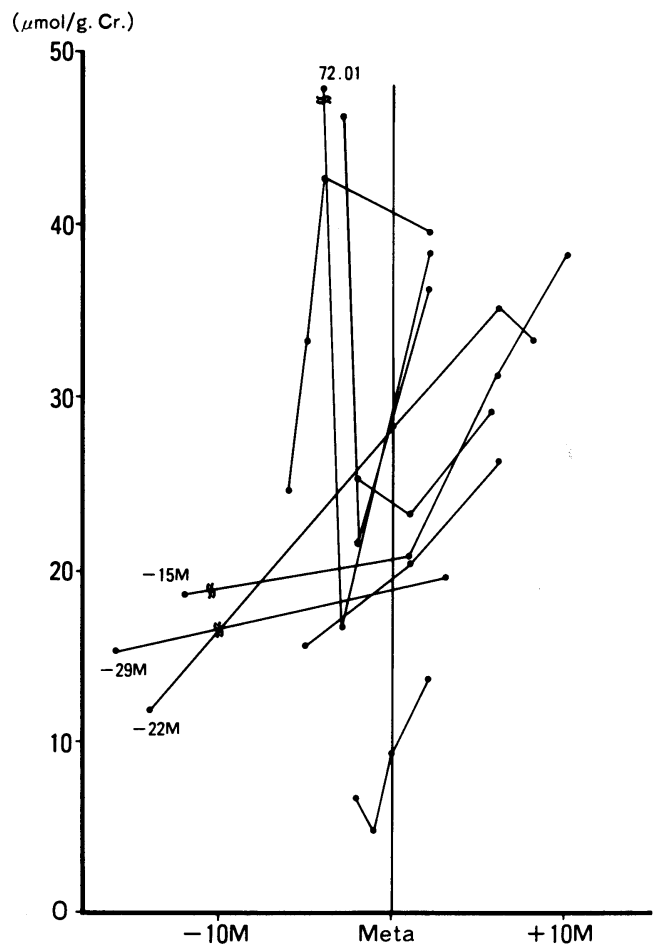

Fig. 9 Changes of diamine levels in urine after nephrectomy

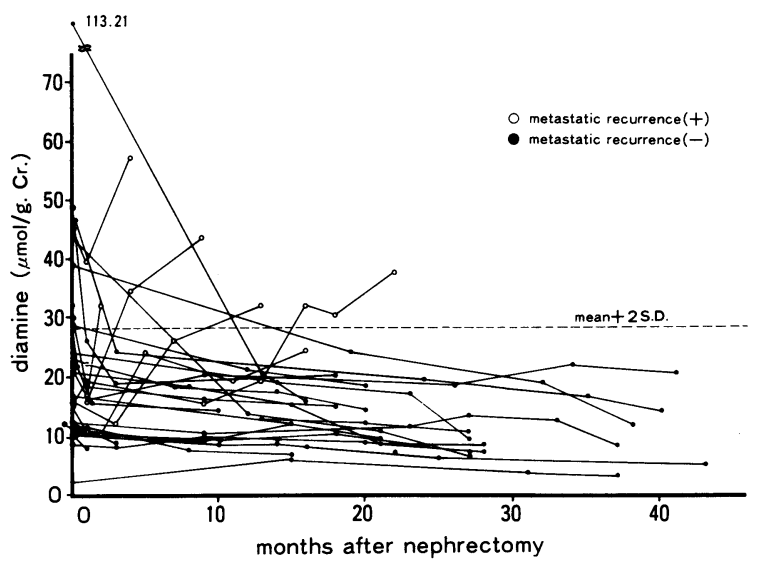

非再発例32例では，Dia をはじめ 3 分画とも治療前に 比し治療後の方が低值を示したが，その後の経過観察 中に著明な上昇を示すものは認められなかった（Fig. 9).さらに，術前に遠隔転移を認めた stage IV の症例 9 例の腎摘出術前後のポリアミン值を比較すると, 治 療前に比し治療後の方が Diaをはじめ 3 分画とも低 值を示し，術後の経過観察においては全身状態の増悪
とともにポリアミン各分画の值も上昇する傾向がみら れた。

健常人群の mean +2 S.D. を越えるものを陽性とし た場合の陽性率について病期別に検討したが， stage I・II は 3 分画とも10３0\%と低い陽性率を示した (Table 4).

4. 組織，血液および尿中ポリアミンの相互関係 腎細胞癌50例の Dia, Spd, Spm について, 組織, 血 液，尿の 3 者間の相関係数を検討した。Diaに関して は, 組織と血液は相関係数 $\mathrm{r}=-0.137$, 組織と尿は $\mathrm{r}=$ 0.225 , 血液と尿は $\mathrm{r}=-0.266$ であり，いずれもよい相 関を示さなかった. Spdに関しては, 組織と血液は $\mathrm{r}=$ 0.113 , 組織と尿は $\mathrm{r}=-0.195$, 血液と尿は $\mathrm{r}=0.061$ と よい相関を示さなかった，Spmにおいては，血液と尿 は $\mathrm{r}=0.405(\mathrm{p}<0.01)$ で相関を示したが，組織と血液 は $\mathrm{r}=-0.044$, 組織と尿は $\mathrm{r}=-0.065$ よい相関は示 さなかった。

\section{考察}

腎細胞癌に打ける組織中ポリアミンの研究として は, Dunzendorfer ら ${ }^{15)} ア ミ ノ$ 酸分析法による腎細胞 癌13例の検討, 松田ら ${ }^{16)}$ のダンシル化薄層クロマトグ ラフ法による26例の検討がある。 Dunzendorfer ら ${ }^{15)}$ は，腎細胞癌では正常腎に比し putrescine (Put)およ び Spd が高值を示し, Spd/Spm 比も.高値を示したと 報告している.松田ら ${ }^{16)}$ は, 腎細胞癌は正常腎皮質に対 し Putおよび Spm で約 2 倍, Spd で約 4 倍の高值を 示し, 腎細胞癌の組織学的悪性度と Spd および Spd/ Spm 比は相関し, Put/Spd 比は逆相関したと報告して いる.さらに松田ら ${ }^{16)}$ は, 腫瘍の組織学的悪性度が高く なるにつれてポリアミン, 特に Spdの組織中濃度が増 加することから, 腎細胞癌の診断や治療効果の判定に おいて，Spdの尿中および血中濃度の測定が有意義で はないかと推定している。

今回の検討では腎細胞癌患者50例について組織だけ でなく, 同時に血液および尿中のポリアミンも測定し， 血液および尿に関しては長期間の経過観察も加えて, 腎細胞癌におけるポリアミンの腫瘍マーカーとしての 意義を次の 4 点から検討した。すなわち，1）早期診 断・スクリーニングの手段としての意義, 2) 腫瘍の組 織学的深達度, 異型度, 細胞型との関連について, 3) 予後を評価する指標としての意義, 4) 治療効果および 再燃の指標としての意義である.

はじめに，早期診断・スクリーニングの手段として の意義であるが，血液および尿中のポリアミンはあま 
り有用でないという評価が多い17)。今回の検討でも血 液拈よび尿中の Dia，Spd，Spmは， stage I・IIにお いていずれも 10 ３0\%前後の低い陽性率しか示さな かった。腎細胞癌のスクリーニングの手段としては, 超音波断層法などの画像診断が確実で, すでに日常化 されている現在，ポリアミンの早期診断における意義 は低いと思われる。

つぎに, 腫瘍の病期, 異型度, 細胞型との関連につ いては, 血液および尿中のポリアミンは癌の病態の進 行とともに上昇すると報告されている ${ }^{17)}$. 今回の検討 でも病期との関係に揖いて, 血中, 尿中の 3 分画とも stage I・II の low stage 群より stage III ・ IV の high stage 群の方が高値を示し, stage III と stage IV との 比較では stage IV の方が高值を示した。これらの血液 扣よび尿中のポリアミンの増加が, 病態が進行するに 従い腫瘍の単位当たりのポリアミン産生能が活発化し ているのか, それとも原発腫瘍組織や転移腫瘍組織な どの腫瘍容積が増大することにより全体としてポリア ミン量が増加しているのかは不明な点が多い，今回の 組織中の検討では， 3 分画とも stage I ・ II より stage III・IV の方が高值を示し, stage III と stage IV との 比較では stage IV の方が高值を示した. 特に, 組織中 の Spd は stage I から stage IVへと進むにつれて高 値を示す傾向がょり顕著であった。これは, 膀胧癌に 抢ける清原 ${ }^{18}$ の研究で, 組織学的深達度を $\mathrm{pT} 1$ 以下の 群と pT1より進んだ群に分けて比較し, 後者の方が組 織中の Put, Spdの含量が有意に高かったことと一致 している. 腎細胞癌の病期の進行とともに, 腫瘍組織 の増殖能掞よび生合成能が上昇して腫瘍自体のポリア ミン産生能も上昇しているものと考えられた。また, 術前に遠隔転移を認めた stage IV の症例 9 例におい て, 腎摘出術により腫瘍容積が減少すると血中お上び 尿中のポリアミン値が低下したことも考文あわせる と, 病期の進行による腫瘍のポリアミン産生能の増加 の他に, 腫瘍容積の増大も加因して血中拉よび尿中の ポリアミンが上昇するものと思われた。

組織学的異型度に関しては, 異型度が高いほど腫瘍 の悪性度が高く増殖能も高いと考光ると, 組織中のポ リアミンとの間に良い相関が得られるのではないかと 思われる。松田ら ${ }^{16)} は$, low grade 群と high grade 群 とを比較し, 後者の方が Spd で有意に高値を示したと 報告している。 今回の検討では, 症例に偏りがあるも のの, 組織中の 3 分画とも, G1よりも $\mathrm{G} 2$, さらには $\mathrm{G} 3$ の方が高值を示し，特にDiaでは G1および G2 と G3
との間に有意差がみられた $(\mathrm{p}<0.01)$. 一方, 異型度 と血液抏よび尿中ポリアミンとの間には，尿中 Dia 以 外はあまりよい相関は得られなかった。血液抢よび尿 中のポリアミン值は, 腫瘍細胞そのものの増殖能だけ でなく, 病期の進行による腫瘍容積の増大などの要素 にも影響されるため, 異型度とあまり相関しなかった ものと思われる。異型度を表す一つの指標としては, 組織中のポリアミン, 特に Dia が有用である可能性が 示唆された。

組織学的細胞型に関しては, clear cell type とそれ 以外の type との間に, 組織, 血液, 尿のいずれの分画 も有意の差は認められなかった。

続いて, 腎細胞癌の予後, 特に転移性再発の可能性 を示す指標としてのポリアミンの意義について検討を 加えた。術前に遠隔転移を認めなかった stage I III の症例41例飞ついて, 転移性再発例 9 例之, 非再発例 32例とを比較検討したところ, 術前の血液および尿中 のポリアミン分画には明らかな差は認められなかった が, 組織中の 3 分画はDia をはじめ転移性再発例の方 が高值を示した。これは, 腎細胞癌について遠隔転移 をきたした症例と，遠隔転移をきたさなかった症例と の間に組織中ポリアミン含量の相違はなかったという 松田ら ${ }^{16)}$ の報告とは食い違ったが，膀胱癌について検 討した清原 ${ }^{18)}$ が，転移性再発例の組織中の Put 拉よび Spd が非再発例に比し有意に高値を示したとしている ことと一致し興味深い. 清原 ${ }^{18)}$ はさらに, 転移性再発例 の組織中 Put/Spd 比が非再発例のそれに比して有意 に高值を示したと報告して抢り，今回の検討でも組織 中 $\mathrm{Dia} / \mathrm{Spd}$ 比は, 非再発例の $0.164 \pm 0.257$ に対し転移 性再発例は $0.539 \pm 1.020$ と高値を示した。 また, stage I・II で転移性再発を示した 3 例のうち, stage I, G2の 症例は組織中 Dia が1.298nmol $/ \mathrm{mg}$ protein と非常に 高く, stage II, G1の症例の組織中 Dia も $0.520 \mathrm{nmol} /$ mg protein と高値を示した. この両者はいずれも組織 中 Spd は高値を示さなかった. stage III の 9 例中 6 例 が転移性再発しているが，転移性再発例の組織中 Dia は非再発例に比し高値を示すものが多かった.さらに, stage I III の G2の症例28例で転移性再発例 5 例と非 再発例23例とを比較検討した結果でも，組織中の Dia は転移性再発例の方が非再発例に比し有意に高値を示 し，組織中の Spd および Spm はそのような傾向を示 さなかった。浪注同じ stage あるいは同じ grade の症 例では, 組織中の Dia の高い方が転移性再発する可能 性が高いのではないかと思われた。清原 ${ }^{187}$ は, その報告 
の中で膀胱癌の予後に関して, 手術時に採取した癌組 織中の Put およびSpd が有用であり，特に再発や転移 を予知する指標として組織中 Put を有力視している. そして，他の悪性腫瘍の末期や，膀羘腫瘍を含む悪性 腫瘍の再発に先立ち，尿中 Put の増加がみられるとい ら報告と考学あわせると非常に興味深いとしてい $ろ^{18)}$.

組織中でのポリアミンの産生は, Put から始まり Spd,さらに Spm へと進む. Russell ら ${ }^{19}$ は尿中の Put 濃度が腫瘍の増殖と良く相関すると述べており, 今回 の検討で組織中でも Dia が腫瘍の増殖能,さらには転 移能を示す指標となる可能性が示唆された，血液およ び尿中のポリアミン濃度は, 腫場自体の増殖能だけに 影響されるのではなく，腫瘍容積の差によるポリアミ ン産生量の差にも大きく影響されるため，ポリアミン の腫瘍における増殖能, 転移能をより正確に知るには 摘出組織中のポリアミンを測定することが望ましいと 思われる．特に組織中の Dia が高值を示すものは，転 移性再発の可能性が高いと思われ，このような症例で は，より慎重な経過観察が必要と思われた。

最後に, 諸家 ${ }^{2171199}$ により有用性が報告されている, 治療効果および再発を示す指標としての血液および尿 中のポリアミンの意義について検討した。転移性再発 例 9 例について検討したところ，腎摘出術を施行して 腫瘍が存在しなくなった時点では血中・尿中の各分画 とも術前に比し低下し，転移性再発を示した後ではい ずれの分画も上昇を示した。特に血中の Spd と尿中の Dia は有意の上昇を示した $(\mathrm{p}<0.01)$ ．これは，腎摘出 術によりポリアミンを著しく産生している腫瘍部分が 消失したため，血液および尿中に排出されるポリアミ ンがいずれの分画も低下し，ついで，転移性再発によ る転移腫瘍病巣でのポリアミン各分画の著しい産生増 加により,血液および尿中のポリアミン, 特に血中 Spd 扣よび尿中 Dia が上昇したものと思われた。非再発例 32例では，血中・尿中各分画とも経過観察中に明らか な上昇はみられなかった。増殖の盛んな腫䁑組織中で は 3 分画とも増加を示しているが，血中で特に増加し ているのは Spd であり, 尿中ではDia であった。これ は, 組織で産生されたポリアミンは血中に出て他の臓 器で代謝されることから, 血中のポリアミン濃度は 3 種のポリアミンの生合成, 分泌, 代謝を反映している ものと考えられ，3 種の中で最も排出されやすいDia が尿中に一番多いものと思われる. 組織中の 3 分画と 血液および尿中の 3 分画との間にはよい相関関係は得
られず，組織に拈ける活発なポリアミンの産生を最も 良く表すのが血中は Spd，尿中は Dia であると考兄ら れ, 治療効果判定および再発の指標として有用である と思われた。

\section{結 語}

腎細胞癌患者50例の血液, 尿, 組織中のポリアミン 濃度を酵素法により分別定量し，その臨床的意義につ いて検討し，以下の結論を得た。

1）腎細胞癌患者群では対照群に比し, 組織, 血液, 尿中の 3 分画とも高值を示し, 組織中の $\mathrm{Spd}(\mathrm{p}<$ $0.01)$, 血中の 3 分画 $(\mathrm{p}<0.05)$, 尿中の Dia 拈よび Spd（p<0.05）は有意差を示した。

2) 組織中の Spd をはじめ組織, 血液打よび尿中の 3 分画とも病期が進むにつれて高值を示した。病期と ともに組織中のポリアミン産生が増加し, 腫瘍容積の 増大と相まって血液掞よび尿中のポリアミンが上昇す るものと思われた。

3）組織学的異型度は, Dia をはじめとする組織中の 3 分画とよく相関した。血液および尿中の 3 分画は尿 中の Dia 以外ではあまりよい相関を示さなかった。異 型度の高い腫瘍は増殖能も高く, 組織中のポリアミン 濃度も高いものと思われた。

4）組織中の 3 分画, 特にDia は転移性再発の有無 と相関した，血液および尿中のポリアミンはあまりよ い相関を示さなかった。

5）治療経過および転移性再発の指標としては, 血中 のSpd 怙よび尿中の Dia が有用であると思われた。

6）血液と尿の Spm の間以外には，組織，血液拉上 び尿の 3 者間に Dia, Spd, Spm のいずれもよい相関関 係は認められなかった。

以上より組織, 血液, 尿中のポリアミンは，それぞ れの特性を考慮して組み合わせることにより, 腎細胞 癌における腫瘍マーカーとして病態を把握するらえで 有意義であると思われた。

稿を終えるにあたり，御指導と御校閲を賜った恩師河田 幸道教授に深甚なる感謝の意を表します。また，直接本研究 を終始御指導下さいました岐阜薬科大学生化学教室沢田英 夫教授, 原 明助教授, 県立岐阜病院泌尿器科部長酒井俊 助博士に深謝致します。

なお, 本論文の要旨は第78回日本泌尿器科学会総会にお いて報告した。

\section{文献}

1) Russell, D.H., Levy, C.C., Schimpff, S.C. and Hawk, I.A.: Urinary polyamines in cancer 
patients. Cancer Res., 31, 1555-1558, 1971.

2) Marton, L.J., Russell, D.H. and Levy, C.C. : Measurement of putrescine, Spd and Spm in physiological fluids by use of an amino acid analyzer. Clin. Chem., 19, 923-926, 1973.

3) Marton, L.J., Heby, O., Levin, V.A., Lubich, W. P., Crafts, D.C. and Wilson, C.B.: The relationship of polyamines in cerebrospinal fluid to the presence of central nervous system tumors. Cancer Res., 36, 973-977, 1976.

4) Russell, D.H. and Durie, B.G.M.: Polyamines as biochemical markers of normal and malignant growth. in Progress in Cancer Research and Therapy, Volume 8, 1st ed., p. 171, Raven Press Co., New York, 1978.

5) Samejima, K., Kawase, M., Sawamoto, M., Okada, M. and Endo, Y.: A sensitive fluorometric method for the determination of aliphatic Dias and polyamines in biological materials by high speed liquid chromatography. Anal. Biochem., 76, 392-406, 1976.

6) 小出卓也, 酒井俊助, 河田幸道, 原 明, 沢田英 夫：新しい酵素法によるポリアミン測定につい て. 第 8 報. 尿路性器癌患者における組織中ポリア ミン分別定量. 泌尿紀要, 36, 1109-1116, 1990.

7）小出卓也, 酒井俊助, 篠田育男, 説田 修, 鄭 漢 彬, 原明, 沢田英夫：新しい酵素法によるポリ アミン測定について.第 5 報。尿路性器癌患者に抒 ける血中ポリアミン分別定量. 泌尿紀要, 32, 919-928, 1986.

8）酒井俊助, 伊藤康久, 小出卓也, 鄭 漢樹, 原 明, 沢田英夫：新しい酵素法によるポリアミン測 定について。第 3 報. 尿路性器癌患者に打ける尿中 ポリアミン分別定量. 泌尿紀要，32，343-350, 1986.

9) Robson, C.J., Churchill, B.M. and Anderson, W. : The results of radical nephrectomy for renal cell carcinoma. J. Urol., 101, 297-301, 1969.

10）日本泌尿器科学会・日本病理学会・日本医学放射線
学会編：泌尿器科・病理・放射線科腎癌取扱い規 約，第 1 版，金原出版，東京，1983.

11）酒井俊助, 伊藤康久, 小出卓也, 鄭 漢彬, 原 明，沢田英夫：新しい酵素法によるポリアミン測 定について. 第 1 報. 本法に打ける尿中ポリアミン 分別定量法の基礎的検討. 泌尿紀要, 32, 327-336, 1986.

12）小出卓也, 酒井俊助, 武田明久, 土井達朗, 鄭 漢 樹, 原明, 沢田英夫 : 新しい酵素法によるポリ アミン測定について.第 4 報. 本法による血中ポリ アミン分別定量の基礎的検討. 泌尿紀要, 32, 913-917, 1986

13）小出卓也, 酒井俊助, 河田幸道, 原明, 沢田英 夫：新しい酵素法によるポリアミン測定につい て. 第 7 報. 本法による組織中ポリアミン分別定量 の基礎的検討. 泌尿紀要, 36, 1103-1108, 1990.

14) Lowry, O.H., Rosebrough, N.J., Farr, A.L. and Randall, R.J.: Protein measurement with the folin reagent. J. Biol. Chem., 193, 265-275, 1951.

15) Dunzendorfder, U. and Russell, D.H. : Altered polyamine profiles in prostatic hyperplasia and in kidney tumors. Cancer Res., 38, 2321-2324, 1978.

16）松田 稔, 長船匡男, 中野悦次, 園田孝夫, 清原久 和：ヒト腎細胞癌の基礎的研究. 第 4 報. 腫瘍組織 内ポリアミン類の含量について。泌尿紀要, 25, $1239-1245,1979$.

17）遠藤康夫, 藤野雅之：Tumor marker による follow up, ポリアミン. 日本臨床, 47, 1142-1146, 1989.

18）清原久和：膀胱腫瘍の生化学的指標に関する研 究. 膀胼癌組織内ポリアミン含量について. 日癌治 誌, 19, 820-831, 1984.

19) Russell, D.H., Durie, B.G.M. and Salmon, S.E. : Polyamines as predictors of success and failure in cancer chemotherapy. Lancet, 2, 797-799, 1975.

（1992年 2 月 3 日受理） 